\title{
The Development of a 9-Item Scale to Measure Anti-Immigrant Attitude toward the Middle East Refugees
}

\author{
Zlatko Šram ${ }^{1 *}$ \\ ${ }^{1}$ Croatian Center for Applied Social Research, Zagreb, Croatia
}

Received 21.05.2020; Received revised 8.12.2020; Accepted 20.12.2020

Available online 31.12 .2020

\begin{abstract}
The aims of this research were (1) to develop a valid and reliable instrument for measuring an antiimmigrant attitude toward the Middle East refugees, (2) to test whether ethnic minority political exclusionism and national attachment and self-sacrifice will associate with the anti-immigrant attitude, and (3) whether the Right-wing authoritarianism (RWA) and Social dominance orientation (SDO) will associate with a hostile attitude toward the Middle East refugees. Confirmatory factor analysis of a 9-item self-report instrument for measuring the anti-immigrant attitude toward the Middle East refugees yielded a single factor underpinned by the components of the triangular theory of hate: passion (fear), the negation of intimacy (repulsion), and commitment (devaluation). Two structural models for prediction the anti-immigrant attitude toward the Middle East refugees were developed. Ethnic minority political exclusionism and national attachment and self-sacrifice were significant predictors of the anti-immigrant attitude. RWA and SDO were also significant predictors of the anti-immigrant attitude. Thus, it appears that a 9-item scale to measure an antiimmigrant attitude toward the Middle East refugees is a valid and reliable self-report instrument.
\end{abstract}

Keywords: immigrants, refugees, Middle East, attitudes, hate theory.

Address of correspondence: Zlatko Šram, Ph.D, Croatian Center for Applied Social Research, Hanamanova 7, 10000 Zagreb, Croatia. E-mail: zlatko.sram@appliedsocresearch.com.

\section{Introduction}

The migration of refugees from the Middle East (Syria, Iraq, and Afghanistan) into the European Union has led to different political reactions influencing both refugee policy and regulation. Public opinion toward the Middle East refugees is relevant for both refugees themselves and those designing policies related to refugees since attitudes toward the Middle East refugees are typically hostile (Yitmen \& Verkuyten, 2018). At any case, the refugees' issue became an important political issue for European countries. Therefore, we considered it essential to analyze the methodological issues related to measuring an antiimmigrant attitude toward Middle East refugees.

The theoretical basis of the anti-immigrant attitude toward the Middle East refugees scale was the Triangular Theory of Hate (TTH) proposed by Sternberg in his duplex theory of hate that presents a triangular theory of structure of hate (Sternberg, 2003, 2005). In other words, we made an endeavor to develop a self-report instrument for measuring a hostile attitude underlying an emotional extreme dislike toward the Middle East refugees and migrants. We aimed to develop such an anti-immigrant attitudinal construct in the articulated theory that would be well supported by empirical data. To the best of our knowledge, there is no similar measure designed to assess negative attitudes towards specific types of migrants or refugees fleeing to Europe. According to the Triangular Theory of Hate, hate comprises three underlying dimensions, which are positively correlated. The first component of hate is the negation of intimacy that involves avoiding a targeted group because it is viewed as being repulsive and disgusted. The second component of hate is the passion that can be expressed either in the form of anger or fear (anger leads one to approach the object of hate while fear leads to avoid the object of hate). In the construction of the anti-immigrant attitude toward the Middle East refugees, we used fear as the subcomponent of the passion component because ,intergroup anger is distinct from intergroup fear" (Sternberg, 2003, p. 308). The third component of hate is the commitment that is characterized by denigration of and contempt for the targeted group. Sternberg (2003) argued that cognitive commitment in hate has a significant role in adopting ,a way of thinking that tends to perpetuate...feelings of hate" (p. 309). 
The second aim of this research was to find out whether and to what degree other ethnic attitudes, such as ethnic minority political exclusionism and national attachment underlying national self-sacrifice contribute to the development or internalization of negativity toward the Middle East refugees. Relying on the conceptualization of ethnocentrism encompassing (a) intragroup ethnocentrism (a sense of strong group cohesion and devotion) and (b) intergroup ethnocentrism (one of the components is a desire to maintain ethnic purity within the ethnic in-group) (Bizumic, Duckitt, Popadić, Dru, \& Krauss, 2009), we considered ethnic minority political exclusionism as an intergroup ethnocentrism based on warlikeness and generally chauvinistic attitudes, whereas national attachment and self-sacrifice we considered as intragroup ethnocentrism based on personal self-transcendence, ethnic identification (Bizumic et al., 2009; Šram, 2016) We have hypothesized that ethnic minority political exclusionism and national attachment and self-sacrifice will be significantly associated with a hostile attitude toward the Middle East refugees.

In additon the the ethnocentrism framework provided by Bizumic and colleagues (2009), the Dual Process Motivation model (DPM; Duckitt \& Sibley, 2010) may also provide insight into how other social attitudes may predict anti-immigrant attitudes towards Middle Eastern refugees. Within DPM model (Duckitt 2001) it is argued that the dual-process motivational model (DPM) proposed that the two basic social or ideological attitudes such as right-wing authoritarianism (RWA; Altemeyer, 2006) and social dominance orientation (SDO; Prato, Sidanius, Stallworth, \& Malle, 1994) represent motivational goals made salient for an individual by his/her personality and social worldview (Duckit, 2006; Duckitt \& Sibley, 2017). Namely, the motivational bases of RWA and SDO are provided by socialized beliefs about the nature of the world. RWA expresses the motivational goal of group security and order obtained through group control, stability, and cohesion and is generated by a view of the social world as dangerous, threatening, and unpredictable (dangerous worldview). SDO expresses the motivational goal of group-based dominance and superiority and ,stems from the social worldview belief that the world is a ruthlessly competitive jungle in which might is right, the strong win, and the weak lose" (competitive worldview) (Sibley \& Duckitt, 2013, p. 451). In the case of SDO, ,the model proposes that the underlying dimension is that of tough-mindedness, characterized by traits of being hard, tough, ruthless, and unfeeling to others" (Duckitt, 2006, p. $685)$. Such a 'social Darwinist' view of the world expresses the motivational goal of group power, dominance, and superiority over others, social attitudes expressed in SDO. Keeping in mind that the anti-immigrant attitude toward the Middle East refugees may represent a pattern of ethnic and racial prejudice, we hypothesized that RWA and Social dominance orientation (SDO; Prato, Sidanius, Stallworth, \& Malle, 1994) will be significant predictors or antecedents of holding hostile attitudes toward refugees (Duckitt \& Sibley, 2010; Dunwoody \& McFarland, 2018; Sibley \& Duckitt, 2013). Hence, the third aim of the research was to investigate whether and to what degree RWA and SDO predict anti-immigrant attitudes toward the Middle East refugees. In such a structural model we aimed to find out the nature of motivational goals or values underlying an extreme emotional dislike toward the Middle East refugees.

\begin{abstract}
Method
Participants and procedure

A convenience sample of the undergraduate and graduate students from the University of Zagreb was formed on which research was carried out. The sample consisted of 212 male and 174 female university students. Ages ranged from 18 to 29 years old $(\mathrm{M}=20.83, \mathrm{SD}=$ 2.07). The current study was carried out on the following faculties of the University in Zagreb: Faculty of Humanities and Social Sciences, Faculty of Political Sciences, Faculty of Kinesiology, Faculty of Natural Sciences and Mathematics, Faculty of Traffic Engineering, and Faculty of Geotechnical Engineering. Participants completed the paper and pencil questionnaires during regular university hours. The faculty authorities approved this study, which was a part of a broader socialpsychological research.
\end{abstract}

\section{Measures}

Assessment of the anti-immigrant attitude toward the Middle East Refugees (ANTIIMM-REF) was based on the 29-item Sternberg and Sternberg's (2008, pp. 217-218) Triangular Hate Scale (THS), using a 5-point Likert scale ranging from 1 (disagree strongly) to 5 (agree strongly). For example, the original item was: „I would never knowingly associate with__. "The verbalization of this item in the THS we applied in our research was: «I would never knowingly associate with these refugees and immigrants.» Thus, the target group in the 29-item THS was ,these immigrants and refugees.“ The only change we made is in the first item of the THT. The original wording was: „I think that_ is truly disgusting“. We changed the word „disgusting“ for "repulsive“ and the item was verbalized: „I think that these immigrants and refugees are truly repulsive". Both versions of the item were based on the component of hate labeled Negation of intimacy (disgust/repulsion). The instruction given to the participants read as follows: „There are very different attitudes toward refugees and immigrants who came and are still coming from Syria, Iraqui, and Afganistan into Europe. To what extent do you agree or disagree with the following statements concerning Syrian, Iraqui, and Afghan refugees and immigrants in Europe? Please, have in mind that there are no correct or incorrect answers. We simply ask you to express your opinion about the feeling toward Syrian Iraqui, and Afghan refugees and immigrants who moved or try to move in Europe, expressing your attitude on a 5-point scale from disagree strongly to agree strongly".

A 4-item scale for assessment of Political exclusionism of ethnic minority is adapted from a Halperin, CanettiNisim, \& Hirsch-Hoefler's (2009) scale of political intolerance. Items of all the scales were rated on a 5-point Likert scale, ranging from 1 (disagree strongly) to 5 (agree strongly). A 4-item scale for assessment of National attachment and self-sacrifice was constructed as the part of the affective dimension of ethnocentrism (Šram, 2010). A 7-item scale for assessment of Right-wing authoritarianism was constructed on the basis of Altemeyer's scale measuring RWA (Altemeyer, 2006). A 5-item scale for assessment for Social dominance orientation was constructed on the basis of the dominance dimension of the SDO scale (Prato, Sidanius, Stallworth, \& Malle, 1994). 


\section{Results}

\section{Preliminary analysis}

An exploratory factor analysis on the 29-item scale measuring an attitude toward the Middle East Refugees was performed using Principal Axis Factoring with Promax rotation. Factor analysis revealed three initial factors explaining $66.85 \%$ of the variance. The extracted factors were highly intercorrelated $(0.75,0.74,0.70)$. The first factor in the Factor Matrix explained even $59.78 \%$ of the variance with eigenvalue 17.66. The factor loadings on the first factor in the Factor Matrix were ranging from 0.66 to 0.85. All these factor analysis outputs have shown the unidimensional characteristic of the THS measured in the sample of the students of the University of Zagreb. In order to develop a short version of the Triangular Hate Scale, we have chosen 9 items from the first factor in the Factor Matrix indicating the components of the hate labeled passion (fear), a negation of intimacy (repulsion), and commitment (devaluation).

In order to test construct validity of the exogenous variables (political exclusion of ethnic minority, national attachment and self-sacrifice, RWA, and SDO, the confirmatory factor analysis (CFA) was conducted by using structural modeling software (Prelis and Lisrel, version 8.54).

CFA of the Political exclusionism of ethnic minority scale yielded a single-factor solution indicating good overall fit for the model $(\chi 2=0.03, \mathrm{df}=2, \mathrm{p}=0.98$, RMSEA $=$ $0.00, \mathrm{CFI}=1.00)$. A demand that ethnic minority be excluded from the political life of the country, underlying the perceived security threat, is the content of the scale (Table 1). Our measure of ethnic minority political exclusionism represents a kind of out-group derogation and indicates to what extent ethnic minorities are perceived as a collective threat to the majority.

Table 1. Ethnic minority political exclusionism (MINEXCL)

\begin{tabular}{lc}
\multicolumn{1}{c}{ Item } & Loading \\
\hline $\begin{array}{l}\text { The members of ethnic minority groups who are not } \\
\text { loyal to our state should be deprived of the citizenship }\end{array}$ & .64 \\
$\begin{array}{l}\text { Ethnic minority political parties should not be allowed } \\
\text { to be the members of our national parliament }\end{array}$ & .77 \\
$\begin{array}{l}\text { There are some ethnic minority groups that should be } \\
\text { encouraged to leave the country }\end{array}$ & .82 \\
$\begin{array}{l}\text { There is no need for ethnic minority groups to be } \\
\text { organized in political parties }\end{array}$ & .64 \\
\hline
\end{tabular}

CFA of the National attachment and self-sacrifice scale yielded a single-factor solution indicating good overall fit for the model $(\chi 2=2.57, \mathrm{df}=2, \mathrm{p}=0.28$, RMSEA $=0.02$, $\mathrm{CFI}=1.00$ ). The existence of a strong affective national attachment underlying the readiness to sacrifice one's life for his/her nation is the content of the scale (Table 2).

Table 2. National attachment and self-sacrifice (NATATT)

\begin{tabular}{lc}
\multicolumn{1}{c}{ Item } & Loading \\
\hline I am ready to die for the dignity of my nation & .81 \\
Love towards my nation is one of the most beautiful & .77 \\
feelings any person can have & \\
The sacred duty of every member of my nation is to & \\
sacrifice his/her personal interests for the benefit of & .86 \\
his/her nation & \\
We must always be ready to defend our national & .67 \\
interests, even by war if necessary &
\end{tabular}

It represents intra-group ethnocentrism that is based on personal self-transcendence and strong ethnic or in-group identification underlying ethnic insecurity (Bizumic, Duckitt, Popadić, Dru, \& Krauss, 2009).

CFA of the RWA scale yielded a single-factor solution indicating good overall fit for the model $(\chi 2 / \mathrm{df}=3.41$, RMSEA $=0.07, \mathrm{CFI}=0.99$ ). The authoritarian submission and authoritarian aggression items defined the content of the scale (Table 3 ).

Table 3. Right-wing Authoritarianism (RWA)

\begin{tabular}{|c|c|}
\hline Item & Loading \\
\hline $\begin{array}{l}\text { It is always better to trust the judgment of the proper } \\
\text { authorities in government and religion than to listen to } \\
\text { the noisy rabble-rousers in our society who are trying } \\
\text { to create doubt in people's mind }\end{array}$ & .67 \\
\hline $\begin{array}{l}\text { The only way own country can get through the crisis } \\
\text { ahead is to get back to our traditional values, put some } \\
\text { tough leaders in prison, and silence the troublemakers } \\
\text { spreading bad ideas }\end{array}$ & .81 \\
\hline $\begin{array}{l}\text { Our country will be destroyed someday if we do not } \\
\text { smash the perversions eating away at our moral fiber } \\
\text { and traditional beliefs }\end{array}$ & .78 \\
\hline $\begin{array}{l}\text { The "old-fashioned ways" and the "old-fashioned } \\
\text { values" still show the best way to live }\end{array}$ & .74 \\
\hline $\begin{array}{l}\text { What our country really needs is a strong, determined } \\
\text { leader who will crush evil, and take us back to our true } \\
\text { path }\end{array}$ & .74 \\
\hline $\begin{array}{l}\text { There are many radicals, immoral people in our } \\
\text { country today, who are trying to ruin it for their own } \\
\text { godless purposes, whom the authorities should put out } \\
\text { of action }\end{array}$ & .79 \\
\hline $\begin{array}{l}\text { Our country will be great if we honor the ways of our } \\
\text { forefathers, do what the authorities tell us to do, and } \\
\text { get rid of the „rotten apples“ who are ruining } \\
\text { everything }\end{array}$ & .83 \\
\hline
\end{tabular}

CFA of the SDO scale yielded a single-factor solution indicating good overall fit for the model $\left(\chi_{2} / \mathrm{df}=2.96\right.$, RMSEA $=0.07$, CFI $=0.99)$. Group-based dominance items defined the content of the scale (Table 4).

Table 4. Social dominance orientation (SDO)

\begin{tabular}{lc}
\multicolumn{1}{c}{ Item } & Loading \\
\hline $\begin{array}{l}\text { In getting what you want, it is sometimes necessary to } \\
\text { use force against other groups }\end{array}$ & .60 \\
$\begin{array}{l}\text { It's OK if some groups have more chances in life than } \\
\text { other groups }\end{array}$ & .62 \\
$\begin{array}{l}\text { If certain groups stayed in their place, we would have } \\
\text { fewer problems }\end{array}$ & .84 \\
$\begin{array}{l}\text { Inferior groups should stay in their place } \\
\text { Sometimes other groups must be kept in their place }\end{array}$ & .88 \\
\hline
\end{tabular}

Reliability and descriptive properties of the exogenous variables

Internal reliability, scale homogeneity (mean inter-item correlations), and descriptive statistics for the exogenous variables are reported in Table 5. The magnitude of the Cronbach alpha coefficients and mean inter-item correlations have shown good intern al reliability and homogeneity of all the measures. The values of skewness and kurtosis indicated normal distributions of the scores in the measures. 
Table 5. Descriptive statistics and mean inter-item correlations (MIC) for exogenous variables

\begin{tabular}{|c|c|c|c|c|c|}
\hline & Alpha & MIC & M (SD) & Sk & $\mathrm{Ku}$ \\
\hline $\begin{array}{l}\text { Ethnic minority } \\
\text { political exclusion }\end{array}$ & .77 & .46 & $\begin{array}{l}10.95 \\
(3.52)\end{array}$ & .01 & -.30 \\
\hline $\begin{array}{l}\text { National attachment } \\
\text { and self-sacrifice }\end{array}$ & .82 & .54 & $\begin{array}{l}11.10 \\
(3.93)\end{array}$ & .09 & -.57 \\
\hline RWA & .89 & .53 & $\begin{array}{l}19.44 \\
(.6 .25)\end{array}$ & $\begin{array}{c}- \\
.23\end{array}$ & -.34 \\
\hline SDO & .84 & .53 & $\begin{array}{l}12.54 \\
(4.14)\end{array}$ & .00 & -.18 \\
\hline
\end{tabular}

Primary analysis

Confirmatory factor analysis of the anti-immigrant attitude toward the Middle East refugees scale

To test the construct validity of a 9-item anti-immigrant attitude toward the Middle East refugees (ANTIIMMREF), the confirmatory factor analysis was conducted. The ANTIIMM-REF scale consisted of 3 items for each theoretical component of the Triangular Hate Scale: (1) passion (fear) - (items: 4, 8, 9); (2) negation of intimacy (repulsion and disgust) - (items: 1, 3, 6); (3) commitment (devaluation/diminution) - (items: $2,5,7$ ). The items are presented in Table 6. CFA yielded a single-factor solution indicating that a measurement model has good overall fit $(\chi 2 / \mathrm{df}=2.96, \mathrm{RMSEA}=0.06, \mathrm{CFI}=0.99)$. The results of the CFA method have shown that the ANTIIMM-REF scale is a highly valid measuring self-report instrument (Figure 1). The magnitude of Cronbach's alpha (0.94) and mean interitem correlation (0.65) have shown excellent internal reliability and homogeneity of the ANTIIMM-REF scale. The values of skewness (0.26) and kurtosis (-0.48) indicated a normal distribution of the scores obtained from the ANTIIMM-REF scale.

Table 6. Right-wing Authoritarianism (RWA)

\begin{tabular}{lc}
\multicolumn{1}{c}{ Item } & Loading \\
\hline $\begin{array}{l}\text { 1. I think that these refugees and immigrants are truly } \\
\text { repulsive }\end{array}$ & .82 \\
2. We need to teach our children about the danger of & .85 \\
people like these refugees and immigrants & \\
3. I would never knowingly associate with these & .85 \\
refugees and immigrants & \\
4. I personally feel threatened by these refugees and & .84 \\
immigrants & \\
5. People need to commit themselves to the fight & .88 \\
against the people like these refugees and immigrants & \\
6. I feel that one cannot trust these refugees and & .87 \\
immigrants & \\
7. People need to take an active role in speaking out & .87 \\
against people like these refugees and immigrants \\
8. These refugees and immigrants are truly frightening \\
9. Thinking about these refugees and immigrants \\
makes me feel insecure
\end{tabular}

Ethnic minority political exclusionism and national attachment and self-sacrifice predicting the anti-immigrant attitude toward the Middle East refugees

Structural equation model was used to test whether ethnic minority political exclusionism and national attachment and self- sacrifice will associate with the antiimmigrant attitude toward the Middle East refugees. The fit indexes indicated good overall fit for the model $(\chi 2 / \mathrm{df}=2.58, \mathrm{RMSEA}=0.06, \mathrm{CFI}=0.98)$. We can see from Figure 2 that ethnic minority political exclusionism (beta $=0.43$ ) and national attachment and self-sacrifice (beta $=0.40$ ) proved to be significant predictors of the antiimmigrant attitude toward the Middle-East refugees. About
$49 \%$ of the variance can be explained by this structural model.

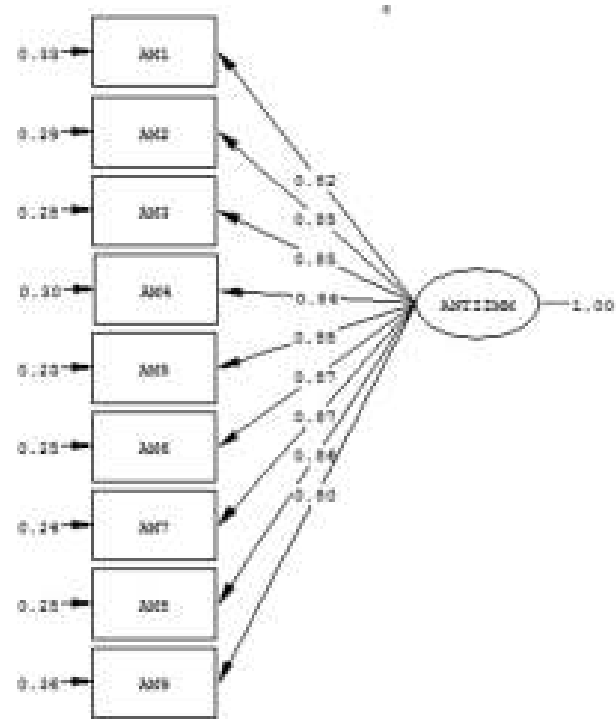

Figure 1. Confirmatory factor analysis of ANTIIMM-REF

Right-wing authoritarianism and Social dominance orientation predicting anti-immigrant attitude toward the Middle East refugees

A structural model for predicting the anti-immigrant attitude toward the Middle East refugees (ANTIIMM-REF) was also developed and evaluated by using full information maximum likelihood estimates. Structural equation model was used to test the theoretical model that Right-wing authoritarianism (RWA) and Social dominance orientation (SDO) will associate with ANTIIMM-REF. The fit indexes indicated good overall fit for the model $(\chi 2 / \mathrm{df}=2.22$, RMSEA $=0.05, \quad C F I=0.99$ ) representing a theoretically based model. We can see from Figure 3 that SDO served as a major source of explained variance (beta $=0.43$ ) in the anti-immigrant attitude toward the Middle East refugees. RWA proved to be also a statistically significant predictor of the ANTIIMM-REF attitudinal construct, but to a much lesser degree (beta $=0.27$ ). About $42 \%$ of the variance can be explained by this structural model.

\section{Discussion}

The primary goal of this research was to develop a short, valid, and reliable instrument for measuring a hostile anti-immigrant attitude toward the Middle East refugees. Confirmatory factor analysis, Cronbach's alpha coefficient and mean inter-item correlation have shown that a 9-item self-report instrument, labeled the ANTIIMM-REF scale, is a valid and highly reliable measure of the anti-immigrant attitude underpinned by the three components of the Triangular Theory of Hate (Sternberg, 2003). Namely, passion (fear), the negation of intimacy (repulsion), and commitment (devaluation) were so much intercorrelated that they formed a unidimensional attitudinal construct on the latent level. In a deeper insight of the psychological nature of the ANTIIMM-REF scale, we can see that (1) passion (fear) is the result of a perceived threat imposed by the refugees, (2) the negation of intimacy indicates the existence of distrust toward the refugees, and (3) 
commitment is indicating aggression toward the refugees Hence, we suggest that a threat-distrust-aggression model serves as a social-psychological frame of reference to explain a hostile attitude toward the Middle East refugees.
It was shown that a complex mix of cognitions, emotions, and behavioral dispositions (Stenberg, 2005) is underlying the content of the ANTIIMM-REF scale.

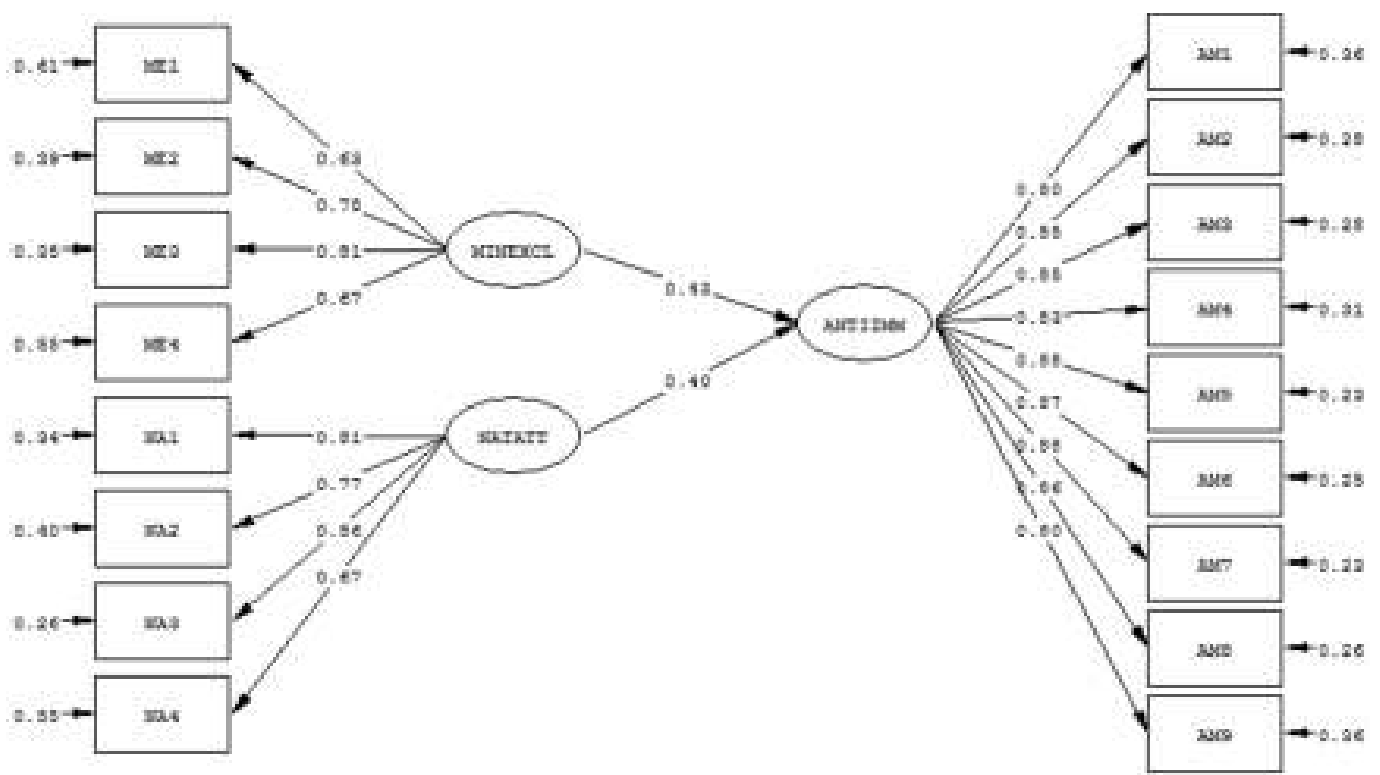

Figure 2. Structural equation model of the effects of ethnic minority exclusionism and national attachment and self-sacrifice on the anti-immigrant attitude toward the Middle East refuges

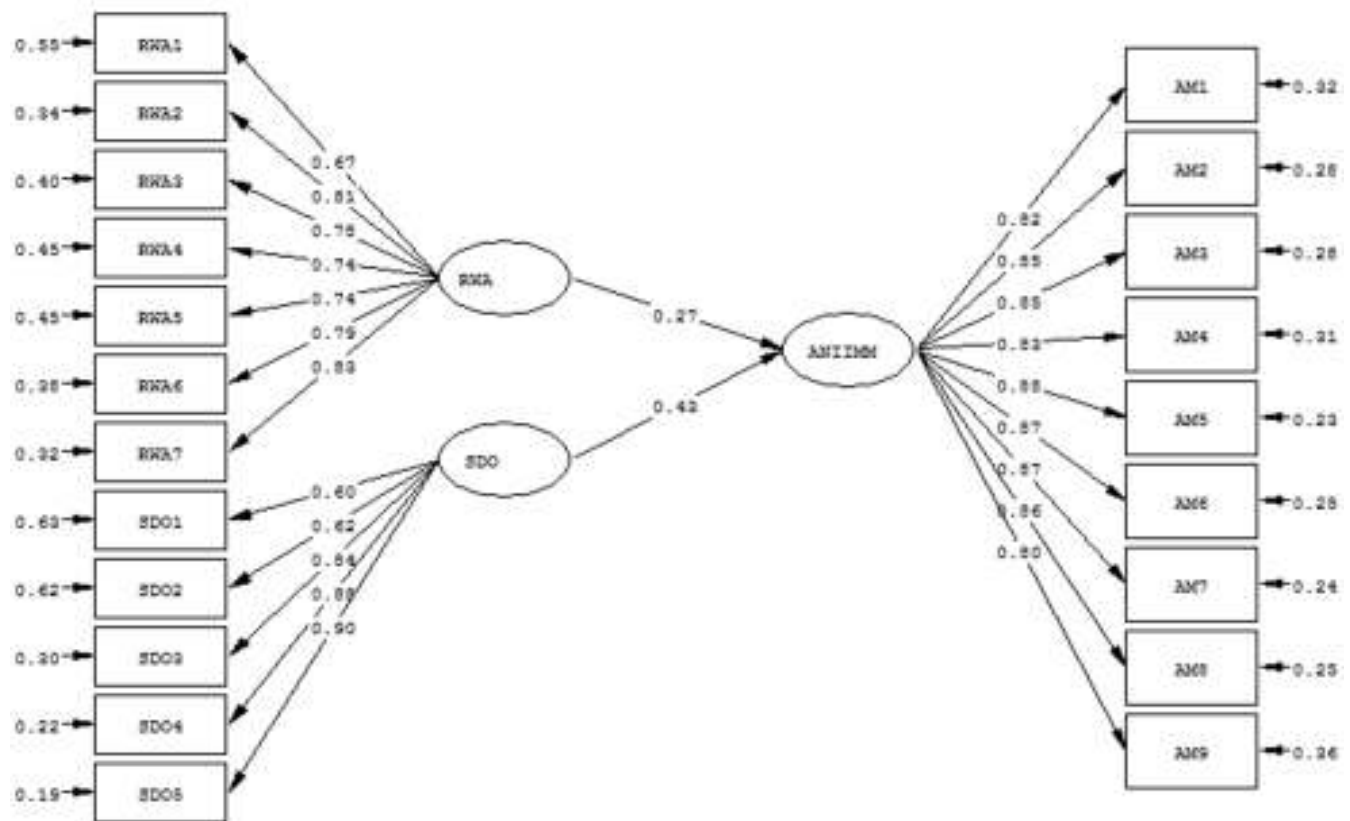

Figure 3. Structural equation model of the effects of Right-wing authoritarianism and Social dominance orientation on the antiimmigrant attitude toward the Middle East refuges

An established close direct relationship between explicit ethnic minority threat and explicit refugee threat indicated the convergent validity of the ANTIIMM-REF scale. This is an additional evidence of construct validity of the instrument measuring a hostile attitude toward the Middle East refugees. An inclination to sacrifice one's life for the benefit and interests of his/her nation, represents a strong ethnic identification, personal self-transcendence
(Bizumic et al., 2009), and a threat to national integrity that includes a threat to group values and morality (Neuberg \& Cottrell, 2002). The covariance of national attachment and self-sacrifice with a hostile attitude toward the refugees is in line with the findings that perception of immigrants as a threat increased as national identification increased (Falomir-Pichastor \& Frederic, 2013). 
It is evident that ethnic minority political exclusionism (intergroup ethnocentrism) and national attachment and self-sacrifice (intragroup ethnocentrism) are motivational and dispositional factors that should be taken into account when explaining a hostile attitude formation toward the refugees and migrants (Dinesen, Klemmenson, \& Norgaard, 2014). In short, an extreme political intolerance toward ethnic minority groups and an extreme national attachment underlying self-sacrifice contribute significantly to the formation of a hostile attitude toward the refugees migrating from the Middle East to Europe. Such an emotional extreme dislike toward the refugees might indicate an outgroup hostility that have survival value in its biological basis (Duckitt, 2010; Bizumic, 2015).

The hypothesis about the impact of RWA and SDO on the hostile attitude toward refugees was confirmed. We saw that both RWA and SDO were proven to be significant predictors. According to the DPM, the Middle East refugees are seen as both socially threatening and socially subordinate because both RWA and SDO predicted a hostile attitude toward them. Namely, these refugees deviate from majority group values and religion and are invariably low in power and status. In this aspect, our findings are in line with those supporting the widely held conclusion that both RWA and SDO predict outgroup prejudice (Duckitt \& Sibley, 2010; Dunwoody \& McFarland, 2018; Duriez \& Van Hiel, 2002; Sibley \& Duckitt, 2013). In other words, both dangerous and competitive worldview are implicitely underlying a hostile attitude toward the refugees. However, we saw in the structural model that SDO is a major source of explained variance in the anti-immigrant attitude toward the Middle East refugees. In other words, it seems that perceiving the world as a ruthlessly competitive and cut-throat jungle contributes much more to the hostile prejudicial attitude toward refugees than does it perceiving the world as a dangerous place.

\section{Limitations and future research directions}

There are some limitations of the study: mono-method assessment (all self-report), college student sample, and cross-sectional design. It is important to note that in future research, the psychometric properties of the ANTIIMMREF scale be examined in ethnically different community samples in Europe. It should also include additional measures of anti-immigrant attitudes that may be correlated with the ANTIIMM-REF scale, showing in this way an additional convergent validity of the scale.

\section{Conclusion}

The purpose of this study was to develop a valid and reliable scale for measuring a hostile attitude underlying emotional extreme dislike toward the Middle East refugees and immigrants. The 9-item scale, labeled the ANTIIMMREF scale, was constructed on the basis of the Triangular Theory of Hate. Construct and convergent validity as well as other psychometric properties of the ANTIIMM-REF scale have shown that the scale is a valid and highly reliable measure for assessing a hostile anti-immigrant attitude. In light of these considerations, we believe that the ANTIIMM-REF scale has much to recommend to researchers who need a useful, efficient, and economical measure of a strong prejudicial attitude that would be investigated in the field of sociology, political science, and psychology research. However, it is important in future studies to examine construct and convergent validity of the scale in community samples and examine relationships between the ANTIIMM-REF and some other self-report measures.

\section{References}

Altemeyer, B. (2006). The authoritarians. Winnipeg, Canada: University of Manitoba (Chapter 1, pp. 10-15).

Bizumic, B. (2015). Ethnocentrism and prejudice: History of the concepts. In J. D. Wright (Editor-in-chief), International Encyclopedia of the Social \& Behavioral Sciences (2nd ed.) (pp. 168-174). Oxford: Elsevier Ltd.

Bizumic, B., Duckitt, J., Popadić, D., Dru, V., \& Krauss, S. (2009). A cross-cultural investigation into reconceptualization of ethnocentrism. European Journal of Social Psychology, 39, 871-899. doi: 10.1002/ejsp.589.

Dinesen, P. T., Klemmensen, R., \& Norgaard (2014). Attitudes toward immigration: The role of personality predispositions. Political Psychology, 37, 55-72. doi: 10.1111/pops. 12220 .

Duckitt, J. (2001). A dual-process cognitive-motivational theory of ideology and prejudice. In M. P. Zanna (Ed.), Advances in experimental social psychology (Vol. 33, pp.41-113). New York, NY: Academic Press.

Duckitt. J. (2006). Differential effects of Right wing authoritarianism and Social dominance orientation on outgroup attitudes and their mediation by threat from and competitiveness to outgroups. Personality and Social Psychology Bulletin, 32, 684-696. doi: 10.1177/0146167205284282.

Duckitt, J. (2010). Historical overview. In J. F. Dovidio, M. Hewstone, P. Glick, \& V. M. Esses (Eds.), The SAGE handbook of prejudice, stereotyping and discrimination. London: SAGE Publications Ltd.

Duckitt, J., \& Sibley, C. G.(2010). Right-Wing Authoritarianism and Social Dominance Orientation differently moderate intergroup effects of prejudice. European Journal of Personality, 24, 583-601. doi: 10.1002/per.772.

Duckitt, J., \& Sibley, C. G. (2017). The dual process motivational model of ideology and prejudice. In C. G. Sibley, \& F. K. Barlow (Eds.), The Cambridge handbook of the psychology of prejudice (pp. 188-221). Cambridge, UK: Cambridge University Press.

Dunwoody, P. T., \& McFarland, S. G. (2018). Support for anti-Muslim policies: The role of political traits and threat perception. Political Psychology, 39, 89-106. doi: 10.1111/pops. 12405.

Duriez, B., \& Van Hiel, A. (2002). The march of modern fascism: A comparison of social dominance orientation and authoritarianism. Personality and Individual Differences, 32, 1199-1213. doi: 10.1016/S01918869(01)00086-1.

Falmoir-Pichastor, J. M., \& Frederic, N. S. (2013). The dark side of heterogeneous ingroup identities: National identification, perceived threat, and prejudice against immigrants. Journal of Experimental Social Psychology, 49, 72-79. doi: $10.1016 /$ j.jesp.2012.08.016.

Halperin, E., Canetti-Nisim, D., \& Hirsch-Hoefler (2009). The central role of group-based hatred as an emotional antecedent of political intolerance: Evidence from Israel. Political Psychology, 30, 93-123. doi: 10.1111/j.14679221.2008.00682.x.

$\mathrm{Hu}, \mathrm{L}$. and Bentler, P. M. (1999). Cutoff criteria for fit indexes in covariance structure analysis: Conventional criteria versus new alternatives. Structural Equation Modeling: A Multidisciplinary Journal, 6, 1-55. doi: 10.1080/10705519909540118.

Kline, R. B. (2005). Methodology in social sciences. Principles and practices of structural modeling (2nd ed.). New York, NY: Guilford Press. 
Neuberg, S. L., \&Cottrell, C. A. (2002). Intergroup emotions: A biocultural approach. In D. Mackie, \& E. Smith (Eds.), From prejudice to intergroup emotions: Differential reactions to social groups (pp. 265-283). New York: Psychology Press.

Prato, F., Sidanius, J., Stallworth, L. M., \& Malle, B. F. (1994). Social Dominance Orientation: A personality variable predicting social and political attitudes. Journal of Personality and Social Psychology, 67, 741-763. doi: 10.1037/0022-3514.67.4.741.

Sibley, C. G., \& Duckitt, J. (2008). Personality and prejudice: A meta-analysis and theoretical review. Personality and Social Psychology Review, 12, 248-279. doi: $10.1177 / 1088868308319226$

Sibley, C. G., \& Duckitt, J. (2013). The Dual Proces Model of ideology and prejudice: A longitudinal test during a global recession. The Journal of Social Psychology, 153, 448466. doi:10.1080/00224545.2012.757544.

Stephan, W. G., \& Stephan, C. W. (1996). Predicting prejudice. International Journal of Intercultural Relations, 20, 409-426. doi.org/10.1016/0147-1767(96)00026-0.

Sternberg, R. J. (2003). A duplex theory of hate: Development and application to terrorism, massacres, and genocide. Review of General Psychology, 7, 299-328. doi.org/10.1037/1089-2680.7.3.299

Sternberg, R. J. (2005). Understanding and combating hate. In R. J. Sternberg (ed.), The psychology of hate (pp. 37-49). Washington, DC: American Psychological Association.
Sternberg, R. J., \& Sternberg, K. (2008). The nature of hate. New York, NY: Cambridge University Press. doi 10.1017/CBO9780511818707.

Šram, Z. (2010). Etnocentrizam, percepcija prijetnje i hrvatski nacionalni identitet (Ethnocentrism, threat perception, and the Croatian national identity). Migracijske i etničke teme (Migration and Ethnic Themes), 26, 113-142. https://hrcak.srce.hr/60862.

Sram, Z. (2016). Evaluating the structure of nationalistic inclinations: Confirmatory factor analysis. Journal on Ethnopolitics and Minority Issues in Europe, 15, 50-74. www.ecmi.de/fileadmin/downloads/publications/JEMIE/2 016/Sram.pdf.

Vitmen, S., \& Verkuyten, M. (2018). Positive and negative behavioral intentions towards refugees in Turkey: The roles of national identification, threat, and humanitarian concern. Journal of Community \& Applied Social Psychology, 28, 230-243. doi: 10.1002/casp.2354

von Hermanni, H., \& Neumann, R. (2019). 'Refugees welcome?' The interplay between perceived threats and general concerns on the acceptance of refugees - a factorial survey approach in Germany. Journal of Ethnic and Migration Studies, 45, 349-374. doi: 10.1080/1369183X.2018.1459183. 